\title{
FOREIGN DIRECT INVESTMENT AND TECHNOLOGY SPILLOVER: EVIDENCE ACROSS INDIAN MANUFACTURING INDUSTRIES
}

\author{
SMRUTI RANJAN BEHERA \\ Email: smrutibehera2003@gmail.com \\ Department of Economics \\ Shyamlal College \\ University of Delhi
}

\author{
PAMI DUA \\ Email: dua@econdse.org \\ Delhi School of Economics \\ University of Delhi
}

\begin{abstract}
BISHWANATH GOLDAR
Email: bng@iegindia.org

V.K.R.V. Rao Centre for Studies in Globalization

Institute of Economic Growth, University Enclave, Delhi
\end{abstract}

Working Paper No. 207

Centre for Development Economics

Department of Economics, Delhi School of Economics 


\title{
Foreign Direct Investment and Technology Spillover: Evidence across Indian Manufacturing Industries
}

\author{
Smruti Ranjan Behera, ${ }^{\mathrm{a} *}$ Pami Dua $^{\mathrm{b}}$ and Bishwanath Goldar ${ }^{\mathrm{C}}$ \\ ${ }^{a}$ Department of Economics, Shyamlal College, University of Delhi, \\ Delhi, India (Email: smrutibehera2003@gmail.com) \\ ${ }^{b}$ Department of Economics, Delhi School of Economics, University of Delhi, \\ Delhi, India (Email: dua@econdse.org) \\ ${ }^{c}$ V.K.R.V. Rao Centre for Studies in Globalization, \\ Institute of Economic Growth, University Enclave, Delhi, India (Email: bng@iegindia.org)
}

The paper attempts to analyze the spillover effect of Foreign Direct Investment (FDI) across Indian manufacturing industries. Foreign presence by way of FDI brings new channels of technology spillover to the domestic industrial firms in the form of enhanced efficiency and diffusion of knowledge in the long-run. By carrying out Pedroni cointegration tests, the analysis tries to provide a long-run relationship between endogenous variables and explanatory variables, pertaining to technology spillovers across Indian manufacturing industries. We find that technology spillovers are relatively higher in industries like food products, textiles, chemicals, drugs and pharmaceuticals and non-metallic mineral products.

Keywords: Foreign Direct Investment; Technology Spillover; Manufacturing; Panel Cointegration; Unit Root Tests.

JEL classification: O41, F43, E23, C22, C23

\footnotetext{
* Corresponding author.

We are thankful to K. L. Krishna and Arup Mitra for their valuable comments and insightful suggestions that have improved this paper considerably. We gratefully acknowledge the comments and feedback we have received from two anonymous referees of the journal which have enabled us to incorporate new ideas in this paper. An earlier version of the paper was presented at the conference on Empirical Issues in International Trade and Finance organized by the Indian Institute of Foreign Trade (IIFT), held on 23-24 December, 2008 at Kolkata. We are thankful to the participants for their valuable comments. The paper was accepted by the World Business Institute (WBI) for presentation at the 9th International Business Research Conference held on 24-26 November, 2008 at Melbourne, and we have benefited from the useful comments of the reviewer of this paper.
} 


\section{Introduction}

Imports and Foreign Direct Investment (FDI) have been recognized as channels for technology spillover. Importing technologically advanced intermediate inputs or commodities might trigger learning that enables the domestic producer to produce similar goods at lower cost at home. FDI might be associated with the spillovers to domestic firms because the workers that embody the firm specific knowledge assets of the Multinational National Enterprises (MNEs) affiliates can be absorbed by domestic firms (Fosuri, Motta, and Ronde, 2001). Because the MNEs have access to new specialized intermediate inputs, whereas domestic firms use local intermediate goods, the productivity of the latter can be raised through the technology know-how of the foreign firms. The technology diffusion of MNEs in the host country and its impact on domestic firms has been the subject of research of many empirical studies (Helpman, 1997). These empirical studies have generally found that there exist significant cross-industry knowledge and technology spillovers in embodied and disembodied forms among large and small size firms. The outcome of the technology spillover impact of FDI on host economies has two linked steps. The first step involves the MNCs parent to subsidiary international transfer of technology that is superior to the prevailing technology in the host country industry. The second step involves the subsequent spread of this technology to domestic firms - a technological spillover effect.

An important aspect of the technology spillover is that these are indeed externalities. Technology spillover occurs when a firm receives economic benefit from another firm's R\&D activity without sharing any cost. This is the significant difference between technology spillover and transfer, i.e., whether the innovator can appropriate the welfare surplus from the transferred knowledge. R\&D innovations and subsequent technological change and spillovers by intermediate factors of production through foreign affiliation or acquisition are important 
factors for economic development by increasing the productivity of domestic firms. The complementary role of MNCs is the diffusion of technology by increasing the productivity growth of domestic firms and it has been widely recognized in the present context. A widely held view is that international trade and the role played by MNCs in the diffusion of technology leads to faster economic growth and helps to achieve higher rates of productivity growth in the host country industry (Ambos, Ambos, and Schlegelmilch, 2006).

FDI is now widely recognized as a catalyst for industrial development in developing countries in view of the fact that it brings new intermediate goods, additional capital for industrial projects, technology transfers and skills in the form of externalities and technology spillovers. The industrial sector in developing countries like India is now under pressure to speed up modernization of its production process in order to survive and face the competition in the global competitive market. The process of economic reforms in India which started in the 1990s, was directed at a systematic shift towards an open economy along with privatization of a large segment of the economy. The removals of quantitative barriers in a phased manner, the lowering of tariff on imports, and the application of suitable tax policy and land acquisition policy, etc., have opened up the Indian economy to international market forces which has led to the rapid emergence of a highly competitive environment, especially in the industrial sector. ${ }^{1}$ This has again emphasized the importance of continuous improvement in productivity, efficiency, and technology spillovers of the industrial sector in India.

Keeping these factors in mind, this study has attempted to empirically estimate the FDI and technology spillover across Indian manufacturing industries. For empirical estimation, sixteen Indian manufacturing industries have been selected, out of which twelve

\footnotetext{
${ }^{1}$ For a recent literature survey, see Athreye and Kapur (2006); Ang (2009) and Madsen, Saxena and Ang, 2010.
} 
are broad 2-digit level industries and four 3-digit level allied industries. ${ }^{2}$ The study has been undertaken at the industry level. It involves an analysis of sixteen selected Indian manufacturing industries. The sample confined to these 16 industries, includes 2,148 firms considered as domestic firms and 231 firms classified as foreign firms. Therefore, the total number of firms in these selected industries is 2,379. Applying the Pedroni (1999, 2000, 2004) panel cointegration tests, the study estimates the long-run relationship between the labor productivity of domestic firms and a set of relevant regressors such as real gross capital stock, capital intensity, foreign presence, technological gap, interaction between market concentration and foreign presence, R\&D intensity of the domestic and foreign firms and technology import intensity (TMI) of the domestic and foreign firms.

The rest of the paper is organized as follows. Section 2 discusses the empirical framework, i.e., it presents a theoretical model which is the background for the empirical estimation and analysis. Section 3 discusses the econometric approaches of panel unit root tests, Pedroni panel cointegration tests, and fully modified OLS (FMOLS), group fully modified OLS (GFMOLS) and dynamic OLS (DOLS) techniques for the empirical models. Section 4 presents and discusses the empirical results and, finally, Section 5 summarizes the findings and gives some policy implications of this analysis.

\section{Empirical Framework}

In this section, we present a theoretical background for the empirical model and its estimation to assess whether the technology spillover arising from foreign presence, R\&D accumulation, and technology imports can contribute to the domestic firms' labor productivity and technology spillovers across industries. Following Romer’s (1990) or Jones’ (1998) R\&D

\footnotetext{
${ }^{2}$ See Appendix B, Table B.1, for the details of the selection.
} 
based endogenous growth models, we specify the production function for output of an industry $i$ at time $t$, denoted by $Y_{i t}$ as being subject to the following functional relationship:

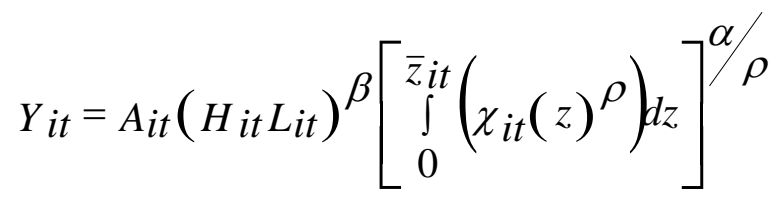

Here $H_{i t}$ is human capital stock, $L_{i t}$ is labor (working labor), $A_{i t}$ is considered as industry-specific factor of industry $i$ at time $t$, with industry-specific constant trend, and $\chi_{i t}(z)$ is intermediate factors continuously distributed over the interval $\left(0, \bar{Z}_{i t}\right)$, where $\bar{Z}_{i t}$ is the varieties of intermediate factors for industry $i$ at time $t$. We assume that $0<\alpha<1$ and $0<\rho<1$, that is, $\alpha \in(0,1)$ and $\rho \in(0,1)$. Thus, total output produced is determined by quality adjusted effective labor and intermediate factors of production in a Cobb-Douglas function. ${ }^{3}$ Now the effective labor can be defined as the raw labor incorporated with human capital and a continuum of intermediate factors are incorporated in CES form. ${ }^{4}$ In a symmetric equilibrium, where $\chi_{i t}(z)=\chi_{i t}$, for all $z \in\left(0, \bar{Z}_{i t}\right)$, all firms producing intermediate factors set the same price and sell the same quantity of each intermediate factors (Kwark and Shyn, 2006). ${ }^{5}$ This implies that the capital stock of an ith industry can be defined as the aggregate stock of intermediate factors:

$$
K_{i t}=\int_{0}^{\bar{z}_{i t}}\left(\chi_{i t}(z)\right) d z=\bar{Z}_{i t} \chi_{i t}
$$

From this discussion, we get the following form of the production function:

$$
Y_{i t}=A_{i t} H_{i t}^{\beta} L_{i t}^{\beta} \bar{Z}_{i t}^{\sigma} K_{i t}^{\alpha}
$$

\footnotetext{
${ }^{3}$ We follow Kwark and Shyn (2006) in specifying our model.

${ }^{4}$ See Mankiw et al. (1992) and Hamilton and Monteagudo (1998) for empirical analysis of the determinants of productivity and economic growth.

${ }^{5}$ Our theoretical intuition in this model is closely linked with the paper by Kwark and Shyn (2006).
} 
From Equation (3), the final output of ith industry at time $t$ is efficiently produced by industry-specific factor $(A)$, human capital $(H)$, labor $(L)$ and intermediate factors are interpreted as capital $(K)$, incorporated with $R \& D$ stocks and technology import intensity (TMI) stock, etc. We interpret $\bar{Z}$ as the varieties of intermediate factors that is R\&D intensity and TMI together (Coe and Helpman, 1995), which has been incorporated with the capital stock. However, in the present analysis we assume that the elements of intermediate inputs which can affect industrial labor productivity are TMI and R\&D intensity at the firm or industry level. ${ }^{6}$ From the above discussion, the final output of ith industry at time $t$ can be efficiently produced by the industry-specific factor, human capital, labor, and intermediate factors which are incorporated with the capital stock $(K)$ that represent R\&D intensity and TMI. Equation (3) has been again written as follows:

$$
Y_{i t}=A_{i t} H_{i t}^{\beta} L_{i t}^{\beta} \bar{Z}_{i t}^{\sigma} K_{i t}^{\alpha} e_{i t}
$$

Here, $e_{i t}$ stands for the random disturbance terms.

Dividing Equation (4) by labor ( $\left.L_{i t}\right)$ on both sides, we get:

$$
\begin{aligned}
& Y_{i t} / L_{i t}=A_{i t} H_{i t}^{\beta} \bar{Z}_{i t}^{\sigma}\left(K_{i t}^{\alpha} / L_{i t}^{1-\beta}\right) e_{i t} \\
& =A_{i t} H_{i t}^{\beta} \bar{Z}_{i t}^{\sigma}\left(K_{i t} / L_{i t}\right)^{1-\beta} K_{i t}^{\alpha+\beta-1} e_{i t}
\end{aligned}
$$

Taking natural logarithm in Equation (5)

$$
\ln \left(Y_{i t} / L_{i t}\right)=\ln \left(A_{i t} H_{i t}^{\beta} \bar{Z}_{i t}^{\sigma}\right)+\beta_{1} \ln \left(K_{i t} / L_{i t}\right)+\beta_{2} \ln K_{i t}+\varepsilon_{i t}
$$

To estimate the technology spillovers across Indian manufacturing industries, we are considering only the labor productivity of domestic firms of an industry $(L P d)$ as the endogenous variable. Thus, Equation (6) can be specified as follows:

\footnotetext{
${ }^{6}$ Coe and Helpman (1995) and Lichtenberg and Van Pottelsberghe de la Potterie B. (1998) pointed out how R\&D spillovers embodied in intermediate factors impacts on total factor productivity (TFP) so that technology spillovers become higher in the long-run. Amiti and Konings (2007) estimate the effects of trade liberalization on plant productivity in Indonesia.
} 


$$
L P d_{i t}=T_{F P}+\beta_{1}\left(k_{i t} / l_{i t}\right)+\beta_{2} k_{i t}+\varepsilon_{i t}
$$

In this equation $L P d_{i t}$ is $\ln \left(Y_{i t} / L_{i t}\right)$, and total factor productivity (TFP) represents $\ln \left(A_{i t} H_{i t}^{\beta} \bar{Z}_{i t}^{\sigma}\right){ }^{7}{ }^{7}$ The small letter symbol represents the natural log form. That is, $\left(k_{i t} / l_{i t}\right)$ and $k_{i t}$ stands for $\ln \left(K_{i t} / L_{i t}\right)$ and $\ln K_{i t}$, respectively. The intermediate factors $(\bar{Z})$ can be split into different factors, based upon the degree of effectiveness of R\&D intensity and TMI. ${ }^{8}$ Further, R\&D intensity can be separated into R\&D intensity of the domestic firms (RDID) and of foreign firms (RDIF) and similarly, TMI can be separated into TMI of the domestic firms (TMID) and of foreign firms (TMIF) (Coe and Helpman, 1995). Further, in place of TFP $A, H$, and $\bar{Z}$, we may use proxies such as industry-specific factor like foreign presence (FORP), quality of labor $(Q L)$, R\&D intensity of the domestic firms (RDID) and of foreign firms (RDIF), TMI of the domestic firms (TMID) and of foreign firms (TMIF).

The quality of labor $(Q L)$ of a particular firm/industry can be proxied by the ratio of number of supervisory and management workers in a firm/industry to total employment of firm/industry (Kohpaiboon, 2006). In addition, as guided by theory and previous empirical works on the determinants of industrial labor productivity and technology spillovers across industries, two additional explanatory variables are used. Firstly, the study takes into account the role of industry-specific factor like technological gap (TGAP) between foreign firms and local firms of an industry and it can be considered as another key determinant for inferences of industrial labor productivity and degree of technology spillovers across industries (Kokko,

\footnotetext{
${ }^{7}$ See Borensztein et al. (1998) for a framework of incorporating the role of FDI by multinational firms as a determinant of economic growth and see Easterly (1993) for a model of technology adoption through international trade and human capital accumulation.

${ }^{8} \mathrm{Xu}$ (2000) empirically estimates the host country productivity growth by total factor productivity (TFP) and TFP increases because of the technology diffusion of the MNEs.
} 
1994). Secondly, market concentration $(M C O N)$ of an industry can be included in the set of explanatory variables as it acts as another determinant for labor productivity over domestic firms and technology spillovers across Indian manufacturing industries. In fact, two industries having the same technical efficiency may show different value-added per worker because of different domestic market concentration. In addition, as argued by Hall (1988), the impact of any possible exogenous factors on industrial labor productivity would be conditioned by the degree of market concentration. As market concentration is one of the control variable, to capture the effect of market concentration, an interaction variable of market concentration and foreign presence $\left(M C O N^{*} F O R P\right)$ is added into the model. Based on these discussions, the empirical model for estimation can be extended to a new model by including these discussed exogenous factors in Equation (7). Now the estimating equation has been specified as follows:

$$
\begin{aligned}
& L P d_{i t}=\beta_{0 i}+\beta_{1}\left(k_{i t} / l_{i t}\right)+\beta_{2} k_{i t}+\beta_{3} F O R P_{i t}+\beta_{4} Q L_{i t}+\beta_{5} R D I D_{i t}+\beta_{6} R D I F i t \\
& +\beta_{7} \text { TMID }_{i t}+\beta_{8} \text { TMIF }_{i t}+\beta_{9} \text { TGAP }_{i t}+\beta_{10} \text { MCON }^{*} \text { FORP }_{i t}+\varepsilon_{i t}
\end{aligned}
$$

\section{Econometric Approaches}

From an econometric point of view, the present analysis follows three familiar steps. The first step is to investigate the stochastic process of the variables involved by means of panel unit root tests. To test the presence of stochastic trends in our data sets, the present analysis employs a battery of panel unit root tests designed explicitly to address the assumption of cross-sectional dependence. The reason for applying several panel unit root tests is to check for the robustness of our results, as the testing strategies vary. Four different approaches of panel unit root test are proposed and used in the present analysis, namely Levin Lin and Chu (LLC); Breitung; Im, Pesaran and Shin (IPS); and Hadri.

The second step consists of testing for cointegration in order to assess for the presence of a long-run relationship between the endogenous variables and exogenous variables in empirical models, which leads to the technology spillovers across Indian manufacturing 
industries in the long-run. This is done by applying the test developed by Pedroni (1999 and 2004) that arguably represents a significant advancement in addressing the lower power of conventional single equation tests for a single time series by exploiting both the cross-section and time series information. Further, due to the unavailability of proper data on the numbers of supervisory and management workers in the firm/industry level obtainable from our principal source of the data set, that is, Centre for Monitoring Indian Economy (CMIE) based 'Prowess', the variable quality of labor $(Q L)$ has been excluded from the estimating Equation (8). Now, in order to conduct the Pedroni cointegration tests in a labor productivity context, the model which is discussed in the empirical section has been specified for the panel cointegration as given below:

$$
\begin{aligned}
& L P d_{i t}=\beta_{0 i}+\beta_{1}\left(k_{i t} / l_{i t}\right)+\beta_{2} k_{i t}+\beta_{3} F_{\text {FRP }} i t+\beta_{4} R_{\text {DID }}+\beta_{5} \text { RDIF }_{i t} \\
& +\beta_{6} \text { TMID }_{i t}+\beta_{7} \text { TMIF }_{i t}+\beta_{8} \text { TGAP }_{i t}+\beta_{9} \text { MCON }^{*} \text { FORP }_{i t}+\varepsilon_{i t}
\end{aligned}
$$

Where $i=1,2, \ldots, 16$ means it covers sixteen Indian manufacturing industries and the time series varies from $t=1,2, \ldots ., 18$, which means it covers the time series data for relevant information from 1990 to 2007. Data sources and construction of the variables are explained in Appendix A. To check the intensity of cointegration we divide the domestic firms into two groups. ${ }^{9}$ These are small size domestic firms and large size domestic firms on the basis of number of employees. Firms, with 500-plus employees come into the category of large size domestic firms and firms with less than 500 employees come into the category of small size domestic firms. Here, we develop two separate cointegrated models which modify Model (9) by changing the endogenous variables, that is, labor productivity over large size domestic firms (LPdbs) and labor productivity over small size domestic firms (LPdsz), and changing

\footnotetext{
9 In order to measure the intensity of cointegration in our empirical models, we apply the Pedroni (1999, 2000, 2004) cointegration tests (seven). If out of the seven statistics, at least four tests are in favour of cointegration, we conclude that cointegration exist in the model. If more than four tests support cointegration, we infer that there is strong cointegration in the model.
} 
the size and scale explanatory variables, capital stock over large size firms ( $k b s)$ and small size firms (ksz) of an industry, capital-intensity over large size firms ( $k b s / l b s)$ and small size firms $(\mathrm{ksz} / \mathrm{lsz})$ of an industry, with other explanatory variables remaining the same as in Model (9). The two separate empirical models discussed that have been specified for panel cointegration are given below.

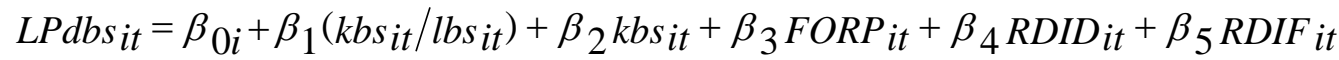

$$
\begin{aligned}
& +\beta_{6} \text { TMID }_{i t}+\beta_{7} \text { TMIF } i t+\beta_{8} \text { TGAP }_{i t}+\beta_{9} M C O N * F_{R O P}+\varepsilon_{i t} \\
& L P d s z_{i t}=\beta_{0 i}+\beta_{1}\left(k_{s z} i t / l s z_{i t}\right)+\beta_{2} k_{s z} i t+\beta_{3} F_{O R P} i t+\beta_{4} R D I D_{i t}+\beta_{5} R D I F_{i t} \\
& +\beta_{6} \text { TMID } i t+\beta_{7} \text { TMIF it }+\beta_{8} \text { TGAP it }+\beta_{9} \text { MCON * FORP it }+\varepsilon_{i t}
\end{aligned}
$$

Then, the third step is to obtain the consistent parameter estimates from the panel cointegration models for which a number of econometric procedures need to be adopted. Most of these arise because of vary nature of the error term $\varepsilon_{i t}$ in the model. If the error terms are independently and identically distributed and uncorrelated with input choices, then the ordinary least squares $(O L S)$ estimates can be consistent but inefficient for the non-stationary unit roots panel data. Using the standard OLS techniques on non-stationary panel data may lead to false inferences in the regression model. Thus, to avoid this kind of inconsistency with respect to the OLS method, the present analysis has used Pedroni (2000, 2001) FMOLS, GFMOLS, and Stock and Watson (1993) DOLS estimates for panel cointegration to estimate the long-run relationship between the cointegrated vectors (Kao and Chiang, 1998).

Pedroni (2000, 2001) FMOLS estimates can capture the heterogeneity across industries (slope and intercept heterogeneity) and permits short-run dynamics. According to Pedroni (2000, 2001), by applying FMOLS, inferences can be made regarding common longrun relationships which are asymptotically invariant to the considerable degree of short-run heterogeneity (as theory suggests), that is prevalent in the dynamics typically associated with 
panels that are composed of aggregate data. The technique, therefore, deals with the endogeneity of the regressors and corrects for serial correlations which may lead to consistent estimates of $\beta$ parameters in relatively small samples. However, before going to a discussion on the empirical results, the statistical summary of the key variables has been given in Table 1.

[Table 1 about here]

\section{Estimation Results}

In the present analysis, panel unit root test of LLC, IPS, Breitung, and Hadri have been applied to check the robustness of the variables and to check for stationarity of the model. The null hypothesis in each case, except Hadri test, is that each series has a unit root and the alternative hypothesis proposes that it allows for some but not all of the individual series having unit roots. Moreover, Hadri Lagrange Multiplier (LM) test is based on the proposition that the null hypothesis contains no unit root against the unit root in the alternative hypothesis of panel data.

[Table 2 about here]

From the reported panel unit root tests (Table 2), it can be seen that most of the tests fail to reject the unit root null for variables in level form (with the exception of the IPS and LLC in three cases), ${ }^{10}$ but the tests reject the null of a unit root in first difference form (Table 3).

\footnotetext{
${ }^{10}$ For the variable $L P d b s$, three out of four unit root tests indicate non-stationary in levels, only LLC indicates stationarity; hence,this series is non-stationary (Ramirez, 2007). Similarly, for the variables RDIF and TMIF three out of four unit root tests indicate non-stationary in levels. So, these variables are considered to be nonstationary in levels.
} 
[Table 3 about here]

The table also reports the widely used Hadri-Z test statistics which uses a null of no unit root. Again, the results of this test are consistent with LLC, IPS and Breitung, ${ }^{11}$ because it rejects the null in favor of a unit root for the variables in first difference form (Ramirez, 2007). Thus, evidence suggests that the variables in the regression model are non-stationary processes and the application of simple OLS to the stacked regression models in (9), (10) and (11) would lead to biased and inconsistent estimates. ${ }^{12}$ Thus, it is necessary to turn to panel cointegration techniques in order to determine whether a long-run relationship exists between the non-stationary variables in level form. Panel cointegration among the non-stationary variables avoids the spurious regression and inconsistency problem at the time of estimation (Rabbaie and Hunt, 2004). Pedroni’s (2004) panel cointegration procedure has been used here to check for cointegration which leads to the long-run relationship between endogenous variables and explanatory variables in our empirical models (9), (10) and (11). The optimal lag length is chosen to be one in all cases based on the Akaike Information Criterion (AIC).

Table 4 presents the results of Pedroni’s (2004) cointegration tests and the reported results in Row 2 of Table 4, that is, the results for cointegrated Model (9) show that out of seven statistics four statistics are rejecting the null of no cointegration (Note: the null is determined by large positive values for panel variance statistics while that for other six is determined by large negative values). The test where the null of no cointegration has been rejected is one where there is a heterogeneous trend specification. The fourth row in Table 4 represents Model (11) and there four statistics are rejecting the null of no cointegration.

\footnotetext{
${ }^{11}$ There are many studies with short panels that have applied LLC, IPS and Hadri tests to check the robustness and stationarity of the variables and similarly, Pedroni (2000) panel cointegration test has been applied in the short panels to check cointegration among the non-stationary variables in levels form.

${ }^{12}$ See Ramirez (2007) for detailed discussion of the application of panel unit roots tests (LLC, IPS, Breitung, and Hadri) and Pedroni $(2000,2004)$ panel cointegration analysis to the short panel data of 1980-2001 in the context of Latin America.
} 
Pedroni developed six statistics besides panel variance statistics, and these provide evidence in support of cointegration between LPdbs and the corresponding regressors in Model (10). This suggests that the cointegration becomes high when the model is considering LPdbs as the endogenous variable and it is regressed with respect to the regressors in Model (10). Hence, when we take productivity of large size domestic firms (LPdbs) as our endogenous variable then the high intensity of cointegration lies in the model, which implies existence of a longrun relationship between $L P d b s$ and the corresponding regressors in the model. Thus, the results clearly point to a significant long-run relationship between labor productivity of domestic firms (whether large/ small size/overall domestic firms) and the discussed explanatory variables in different models, and these long-run relationships obviously lead to technology spillover across Indian manufacturing industries.

\section{[Table 4 about here]}

Table 5 gives panel GFMOLS and DOLS estimates after estimating models (9), (10) and (11). ${ }^{13}$ The results reported in Table 5 suggest that foreign presence coefficients are positive and significant for GFMOLS and DOLS estimates in Model (9), for DOLS in Model (10), and for GFMOLS and DOLS in Model (11), which suggests that all sizes of domestic firms corresponding to the different manufacturing industries gain from technology spillovers. This implies that our categorical division of the sizes of firms does not make much difference for the absorptive capacity and spillovers from the foreign firms. From this empirical exercise,

\footnotetext{
${ }^{13}$ The FMOLS estimator directly estimates the long-run relationship by correcting the simple OLS estimator for serial correlation and endogeneity problem in model. To do the robustness check in model the DOLS procedure has been added in the empirical estimation including one leads and one lags for the differenced regressors and regressing I (1) variables on the I (1) variables, the I (0) variables leads and lags of the first difference of the I (1) variables, and constant. The DOLS procedures corrects for potential endogeneity problems and small sample bias, and provide estimates of the cointegrating vectors which are asymptotically efficient.
} 
it appears that there is the existence of technology spillovers in all sizes of domestic firms. The results in respect of scale variables, capital intensity and real gross capital stock make sense for the estimated models for technology spillovers because these variables are statistically significant and have correct signs with respect to our three empirical models.

[Table 5 about here]

The coefficients for interaction variable of market concentration and foreign presence are found to be statistically significant in some estimates of the models. This finding suggests that the interaction variable has played a significant role in generating technology spillovers among different sizes of the domestic firms and further it leads to the technology spillovers across manufacturing industries in India. Kokko (1992) was the first to point out that the existence of spillovers can be a function of the technological level of MNCs affiliates compared to that of domestic firms. ${ }^{14}$ If the technological gap between the two sets of firms is too large, then domestic firms may not be able to benefit from the introduction of new technology. In fact, the foreign technology may be too advanced to allow for any interaction with domestic firms. According to Findlay (1978) small technological gap seems to spur spillovers from FDI. From the results obtained in this study, the coefficients for technological gap are found to be non-positive and statistically significant in a majority of estimates corresponding to the different models. This suggests that the technological gap has played a negative role in influencing the technology spillovers across Indian manufacturing industries. Further, this line of reasoning suggests that higher the technological gap between foreign and local firms, the lesser are the benefits to local firms from foreign investment because of the low absorptive capacity and low learning ability of the local firms and ultimately lower would be the technology spillovers.

\footnotetext{
14 See also Haddad and Harrison, 1993; Kokko, 1994; Wang and Blomstrom, 1992 and Blomstrom and Kokko, 1998.
} 
It is evident from this empirical exercise that with a few exceptions, R\&D intensity of the domestic firms and TMI of domestic firms are found to be statistically significant with correct positive signs. From the results for R\&D intensity of the foreign firms and TMI of foreign firms, it will be observed that only in a few cases these coefficients are statistically insignificant. This line of reasoning suggests that the positive effect of TFP leads to higher technology spillovers across Indian manufacturing industries. Further, TFP depends on the own R\&D intensity of the domestic firms and R\&D intensity of the foreign firms, TMI of the domestic firms and foreign firms cumulative imported technology is embodied in imported intermediate inputs and, therefore, technology may have been transmitted via import intensity and import-weighted stock of knowledge.

Table 6 reports the individual FMOLS results for the empirical Model (9) over the period 1990-2007 across sixteen Indian manufacturing industries. The coefficients of real gross capital stock and capital intensity are found to be non-negative and statistically significant in most of the industries. In chemical and consumer electronics industries the coefficients of capital intensity are found to be statistically significant but with negative signs. ${ }^{15}$ This finding suggests that for both industries capital intensity cannot augment their productivity spillovers. The coefficients of capital stock achieves robust economic and statistical significance in most of the industries and has correct positive sign except in a few industries like leather products, chemicals, and rubber products industries. This finding suggests that except in a few industries, capital stock has played a favorable role in increasing labor productivity and technology spillovers across Indian manufacturing industries.

\footnotetext{
${ }^{15}$ The incorrect sign of the coefficient of capital intensity in chemicals and consumer electronics industry may be because of multicollinearity between capital intensity and capital stock. The variables are retained since the main objective is to examine the technology spillovers across Indian manufacturing industries and the key results are not significantly affected even after including both insignificant capital and capital intensity variables in some industries.
} 
[Table 6 about here]

The next key inference for technology spillovers across Indian manufacturing industries is foreign presence. It is generally believed that local participation with multinationals reveals the MNCs proprietary knowledge, and in that way facilitates technology spillovers to the domestic sectors. Our findings indicate that the coefficients of foreign presence are statistically significant in most of the industries with expected positive signs. This suggests that the higher the foreign presence, the higher would be the TFP and, finally, it can enhance more technology spillovers to the domestic firms of Indian manufacturing industries. However, the technology spillovers are relatively higher in industries like food products, textiles, chemicals, drugs and pharmaceuticals and in nonmetallic mineral products. ${ }^{16}$ However, there are still other manufacturing industries which show the existence of the technology spillovers effect form FDI. Further, the competitive pressure from FDI is likely to gravitate to the domestic firms in order to exist in the global market. Foreign presence in an industry may increase competition and force domestic firms to become more efficient. Thus, foreign presence seems to be an important determinant of labor productivity and productivity spillovers in Indian manufacturing. Further, the larger the share of foreign ownership the larger is the scope for technology spillovers.

The coefficients of the interaction variables for market concentration and foreign presence are found to be non-negative and statistically significant in almost all industries, with a few exceptions like food products, beverages and tobacco, cotton textiles industry, and

\footnotetext{
16 There has been a separate estimation of individual FMOLS estimates for the empirical Models (10) and (11). But we find that the empirical results across different manufacturing industries are not varied as in comparison to the results of Model (9) in Table 6. The important finding is that the five mentioned industries are again dominating higher technology spillovers in Models (10) and (11). Thus, we are not discussing the individual FMOLS estimates for empirical Models (10) and (11).
} 
non-metallic mineral products industry for which the coefficients are found to be negative. For industries with non-negative coefficients of the interaction variable, it may be inferred that market concentration leads to higher productivity of the domestic firms and can bring about more technology and knowledge spillover to the industries. The coefficients for technological gap are found to be negative and statistically significant in almost all sixteen Indian manufacturing industries. Thus, the inference that can be drawn from this empirical exercise is that the higher the technological gap between foreign and local firms, the lower would be the labor productivity and technology spillovers. Moreover, it seems reasonable to expect the relationship between technology gap and spillovers to be non-linear (Chen and Kokko, 2010). Further, some technological gap is required for spillovers to take place, and at an initial stage the degree of spillovers may rise with the size of technology gap. However, beyond a certain level the gap may be so large that it will be impossible for the domestic firms to absorb foreign technology with their existing experience, educational level and technological knowledge (Sjoholm, 1999). From this exercise and previous literature, it seems reasonable to argue that higher technological gap enlarges the imitation problems and minimizes the absorptive capacity of the localized firms in an industry. As a result, labor productivity would be lower and spillovers to the domestic firms of Indian manufacturing industries would be limited.

Knowledge and technology spillovers can be transmitted via the quality and variety of intermediated inputs, predominantly explained by R\&D intensity of domestic firms and foreign firms, TMI of domestic and foreign firms. It is argued that firms’ absorptive capacity is crucial for realizing technology spillovers (Girma, 2005). R\&D is often represented as an important indicator of local firms’ absorptive capacity. It is evident that the coefficients of R\&D intensity of domestic firms are found to be positive and statistically significant in the 
results for most of the manufacturing industries. Going by this line of reasoning, the higher the R\&D intensity, the higher would be the labor productivity and technology spillovers across Indian industries. The coefficients of R\&D intensity of the foreign firms are found to be non-negative for some industries and in some industries it is found to be negative and statistically significant. Thus, it is evident that for industries with coefficients bearing nonnegative signs, R\&D has played a significant role for enhancing labor productivity of the domestic firms and it can increase the technology spillovers across Indian manufacturing industries. This is the positive externality which can lift up the knowledge and technology spillovers to the domestic firms, if foreign firms are increasing their $R \& D$ expenditure then domestic firms have to increase their R\&D expenditure in order to face the competition on the one hand and survive in the market on the other hand. Similar inferences can be drawn with respect to the TMI of the foreign firms.

In the results reported in Table 6, the coefficients for TMI of the domestic firms are non-negative and statistically significant in most of the industries. This evidence suggests that the higher the TMI of the domestic firms higher would be the TFP. Further, it can facilitate the assimilation of knowledge embodied in imported technology and, thereby, raise the absorptive capacity of the domestic firms and can lift up higher technology spillover to the Indian manufacturing industries over the long-run. Finally, in some Indian manufacturing industries, the coefficients of TMI of foreign firms are found to be non-negative and statistically significant. This suggests that the productivity and spillovers becomes higher over domestic firms if foreign firms in an industry are increasing their technology up-gradation by importing more sophisticated technology then the domestic firms have to undertake more technology up-gradation in order to improve their product quality at cheapest cost. 


\section{Concluding Remarks}

The present study empirically examined the FDI and technology spillovers across Indian manufacturing industries. Panel cointegration tests were carried out with respect to our different empirical models. The empirical evidence based on Pedroni (2000, 2004) cointegration tests showed the presence of a significant long-run relationship between labor productivity in large size domestic firms and its determinants in the empirical model. However, from the different empirical models estimated, there is indication of presence of cointegration and the existence of technology spillovers among not only large firms, but also among relatively smaller firms. Thus, the presence of cointegration and the existence of technology spillovers are found for different sizes of the domestic firms. These cointegration results, based on panel data from 1990 to 2007 across sixteen Indian manufacturing industries suggested that foreign presence played a significant role in lifting the level of technology of the domestic firms through technological spillovers. Particularly, in most of the manufacturing industries there exists a long-run relationship between foreign presence and labor productivity over the domestic firms. In fact, foreign presence has been positively associated with labor productivity, knowledge and technology spillovers. Therefore, foreign presence by way of FDI brings new channels of knowledge and technology to the domestic firms and further, it can facilitate higher productivity and technology spillovers.

The empirical results provide supporting evidence that TFP is a positive function of R\&D intensity of domestic and foreign firms and technology import intensity (TMI) of both domestic and foreign firms. Technology spillovers can be transmitted via different types of intermediate factors, and from this result it was evident that a rise in the TMI gained momentum for the improvement of labor productivity over domestic firms and technology spillovers across Indian manufacturing industries. Both R\&D intensity and TMI can facilitate 
in raising the knowledge and technology spillovers through the channel of imports. Thus, we may infer that there is a positive association between R\&D intensity and TMI with respect to labor productivity and technology spillovers. The results also highlight the important role of TMI of the foreign firms in increasing the labor productivity of the domestic firms. Our findings indicate that the higher the TMI of the foreign firms, the higher would be the TMI of the domestic firms in order to compete in the market. Thus, the TMI of the foreign firms can in an indirect way generate positive externality for the domestic firms to improve their labor productivity. Our findings also suggest that except for a few manufacturing industries the capital stock, capital intensity, and the interaction variable involving market concentration and foreign presence has played an important role to facilitate the improvement of labor productivity and technology spillovers among domestic firms. Technological gap between foreign firms and local firms has had a negative effect on the productivity of domestic firms, and our findings suggest that higher the technological gap, the greater will be the imitation problem and hence the lower the absorptive capacity of the domestic firms leading to lower technology spillovers.

Finally, the findings of this paper have important implications for raising the labor productivity and technology spillovers across Indian manufacturing industries. FDI is now considered to be a key growth enhancing factor in investment receiving host country like India. FDI not only brings capital but it also introduces advanced technology to the host country firms. Thus, it can narrow down the technological gap between foreign firms and local firms. The policy authority of Indian government can consider initiative policy to attract more foreign capital by adopting a suitable policy regime, land acquisition policy, and labor laws. The higher the inflow of foreign capital, the higher would be the application of advanced technology, which would minimize the technological gap between foreign and local 
firms. There must be proper coordination between government and private parties so that domestic firms can take the best advantage of the policy regime and therefore, it can easily learn and wherever necessary import more advanced technology from foreign firms. This advantage definitely brings new initiative to domestic firms and therefore, domestic firms are able to emulate foreign technology and raise their labor productivity and technology spillovers.

\section{Data}

\section{Appendix A}

The data in this paper mainly comes from the Centre for Monitoring Indian Economy (CMIE) based corporate data set 'Prowess', Annual Survey of Industries (ASI), and National Accounts of Statistics (NAS).

\section{Variables}

\section{Labor productivity}

LPd: The labor productivity at the firm level has been constructed by dividing the gross value added to the number of man-days (labor) of firm of an industry. The analytical estimation has been based on the industry level, so the labor productivity has been constructed to the industry-specific variable. To make labor productivity as an industry-specific variable and to get the spillover effect across Indian manufacturing industry we simply take average of the labor productivity over domestic firms in an industry for a specific period of time.

LPdbs: Average of the labor productivity over large size domestic firms in an industry for a specified time period.

LPdsz: Average of the labor productivity over small size domestic firms in an industry for a specified time period.

Capital (k): For the present study, to construct the capital variable from the Prowess data set we followed the methodology, derived by Srivastava (1996) and Balakrishnan et al. (2000). 
They used the perpetual inventory method, which involves capital at its historic cost. Thus, the direct interpretation of the perpetual inventory method is not an easy task. Therefore, the capital stock has to be converted into an asset value at replacement cost. The capital stock is measured at its replacement cost for the base year 1993-94. Then, we followed the methodology of Balakrishnan et al. (2000) to arrive at a revaluation factor. The revaluation factors $R^{G}$ and $R^{N}$ for initial year's gross and net capital stock, respectively, have been obtained as follows:

The balance sheet values of the assets in an initial year have been scaled by the revaluation factors to obtain an estimate of the value of capital assets at replacement cost. ${ }^{17}$ However, the replacement cost of capital $=R^{i} *$ (value of capital stock at historic cost), where, $i$ stands for either gross $(\mathrm{G})$ or net $(\mathrm{N})$ value. The formula for the revaluation factor for the gross fixed asset $R^{G}$ and value of the capital stock at its historic cost $G F A_{t}^{h}$ is given below:

$$
G F A_{t}^{h}=P_{t} I_{t} *((1+g)(1+\pi) /(1+g)(1+\pi)-1)
$$

where, $P_{t}=$ Price of the capital stock; $I_{t}=$ Investment at the time period $t(t=1993)$; $=$ the difference between the gross fixed assets across two years, that is, $I_{t}=G F A_{t}-G F A_{t-1}$; $\mathrm{g}$ stands for the growth rate of investment, that is, $g=\left(I_{t} / I_{t-1}\right)-1$ and $\pi=\left(P_{t} / P_{t-1}\right)-1$. The revaluation factor for the gross fixed asset is $R^{G}=(l+g)(l+\pi)-1 / g(1+\pi)$. Here, $l$ stands for the life of the machinery and equipment. Thus, the revaluation factor has been constructed by assuming that the life of machinery and equipment is 20 years and the growth of the

\footnotetext{
${ }^{17}$ See Srivastava $(1996,2000)$ for detailed discussion of the perpetual inventory method to compile the real gross capital stock from the CMIE based Prowess data set.
} 
investment is constant throughout the period. We assume that the price of the capital stock has been changed at a constant rate from the date of incorporation of the firm to the later period, i.e., up to 2007. The revaluation factor which has been obtained is used to convert the capital in the base year into the capital at replacement cost, at current prices. We then deflate these values to arrive at the values of the capital sock at constant prices for the base year. The deflator used for this purpose is obtained by constructing capital formation price indices from the series for gross capital formation from the NAS. Then, subsequent year's capital stock is arrived at by taking the sum of investments, using the perpetual inventory method. ${ }^{18}$

Labor (l): For the present study, our principal source of the data base is Prowess. Our analysis is based on the Prowess data set. However, the Prowess data base does not provide the exact information regarding labor per firm. Thus, we need to use this information on man-days per firm. Man-days at the firm level are obtained by dividing the salaries and wages of the firm to the average wage rate of an industry to which the firm belongs. ${ }^{19}$ Thus, the man-days per firm are as given below:

Number of man-days per firm = salaries and wages/average wage rate

To get the average wage rate, we used the information from ASI data. ASI contains information on total emoluments and total man-days for the relevant industry groups. The average wage rate can be obtained by dividing the total emoluments to the total man-days for relevant industry groups.

\footnotetext{
${ }^{18}$ To get the capital stock over large size ( $\left.k b s\right)$ and small size firms' (ksz) of an industry we are using this same perpetual inventory method.

${ }^{19}$ For the present analysis when we compiled the labor variable from CMIE based Prowess data set and from ASI sources, then information's for total man-days and total emoluments in ASI data were available up to 2004-05. Thus, from ASI data we extrapolating the data range from 2004-05 to 2007 to get the average wage rate of an industry.
} 
Average wage rate $=$ total emoluments $/$ total man-days

Capital Intensity $(k / l)$ : Capital intensity at the firm level can be obtained by dividing the real gross capital to the labor of that firm. To get capital intensity as an industry-specific effect, we simply divide the summation over all firms' capital stock to the summation over all firms' labor of an industry.

kbs/lbs: To calculate the capital intensity over large size firms as an industry-specific variable, we divide the summation over all large size firms capital stock to the summation over all large size firms' labor of an industry.

ksz/lsz: To calculate the capital intensity over small size firms as an industry-specific variable, we divide the summation over all small size firms capital stock to the summation over all small size firms’ labor of an industry.

Foreign Presence (FORP): Foreign presence is measured by the output share of foreign firms to the total industry output. However, in some previous empirical studies, employment or capital shares have been used to measure the foreign presence. Taking foreign presence as an employment share tends to underestimate the actual role of foreign affiliates because MNEs affiliates tend to be more capital intensive than local non-affiliated firms. On the other hand, the capital share can be easily distorted by the presence of foreign ownership restrictions. Hence, output share is the preferred proxy (Kohpaiboon, 2006).

Technological Gap (TGAP): Technological gap between foreign firms and local firms is proxied by the ratio of average value added per worker of the foreign firms to that of local firms.

Interaction variable $\left(M C O N^{*} F O R P\right)$ : For the present study to measure the market concentration, we take widely used proxies of Herfindahl-Hirschman index of concentration $(H H I)$. The $H H I$ of market concentration formula is given below: 
$H H I=\sum_{i}\left(s_{i j} / \sum_{s i j}\right)^{2}$

where $s_{i j}$ is a total sale of the $i$ th firm in the $j$ th industry. To calculate the interaction variable, we multiply the $H H I$ market concentration to the foreign presence of an industry.

\section{R\&D Intensity}

RDID: The R\&D intensity at the firm level is measured by the share of $\mathrm{R} \& \mathrm{D}$ expenditure to total sales. To make the R\&D expenditure over the domestic firms (RDID) as an industryspecific variable, we measured the total $R \& D$ expenditure over the domestic firms by summing R\&D expenditure over all the domestic firms in an industry, and divide by the total sales of all firms by again summing the sales of each domestic firm of that industry, for that specified period.

$R D I F$ : To calculate the R\&D expenditure of foreign firms (RDIF) as an industry-specific variable, we divide the sum of $R \& D$ expenditure of all foreign firms in a specific industry to the sum of the total sales of all foreign firms in that industry.

\section{Technology Import Intensity (TMI)}

The technology imports can be broadly classified into two categories as embodied technology, consisting of imported capital goods and disembodied technology consisting of blue prints and license fees, as this is considered as remittances on royalty and license fees. Hence, the TMI at the firm level can be obtained by dividing the summation over embodied and disembodied technology to the total sales of the firm.

TMID: To calculate the TMI of domestic firms (TMID) as an industry-specific variable, we divide the sum of the total disembodied and embodied technology over all domestic firms in an industry to the total sales of that industry by again summing the sales of all domestic firms for a specified time period. 
TMIF: To calculate the TMI of foreign firms (TMIF) as an industry-specific variable, we

divide the sum of the total disembodied and embodied technology over all foreign firms in an industry to the total sales of that industry by again summing the sales of all foreign firms for a specified time period.

\section{Appendix B}

Table B.1. Classification of firms across Indian manufacturing industries in 2007

\begin{tabular}{|l|l|l|l|l|}
\hline NIC 1987 CODE & Industry Classification & Domestic Firms & Foreign Firms & Total Firms \\
\hline $20-21$ & Food Products & 146 & 12 & 158 \\
\hline 22 & Beverages and Tobacco & 85 & 4 & 89 \\
\hline 23 & Cotton Textiles & 307 & 4 & 311 \\
\hline 26 & Textiles & 245 & 13 & 258 \\
\hline 27 & Woods Products & 20 & 1 & 21 \\
\hline 28 & Paper and Paper Products & 40 & 5 & 45 \\
\hline 29 & Leather Products & 14 & 1 & 15 \\
\hline 30 & Chemicals & 410 & 77 & 487 \\
\hline $304(30)$ & Drugs and Pharmaceuticals & 117 & 21 & 138 \\
\hline $312(31)$ & Rubber and Rubber Products & 12 & 2 & 14 \\
\hline 32 & Non-metallic Mineral Products & 96 & 14 & 110 \\
\hline 34 & Metal Products & 176 & 24 & 200 \\
\hline 35 & Non-Electrical Machinery & 229 & 26 & 255 \\
\hline 36 & Electrical Machinery & 226 & 21 & 247 \\
\hline $365(36)$ & Consumer Electronics & 6 & 2 & 8 \\
\hline $375(37)$ & Automobiles & 19 & 4 & 23 \\
\hline
\end{tabular}

Source: Based on own calculations from the CMIE data set 'Prowess'.

Note: 1. FDI firms (foreign firms) are those firms with foreign equity of 10 percentages or more than of 10 percentages.

2. According to National Industrial of Classification (NIC) the four 3-digit level industries are drugs and pharmaceuticals (304) coming under chemicals (30), rubber and rubber products (312) coming under rubber and plastic products (31), consumer electronics (365) coming under electrical machinery (36), and automobiles (375) coming under the transportation industry (37). 


\section{References}

Ambos, T, B Ambos and BB Schlegelmilch (2006). Learning from foreign subsidiaries: an empirical investigation of headquarters benefits from reverse knowledge transfers. International Business Review, 15(3), 294-312.

Amiti, M and J Konings (2007). Trade Liberalization, Intermediate Inputs, and Productivity: Evidence from Indonesia. American Economic Review, 97, 1611-1638.

Ang, JB (2009). Do financial sector policies promote innovative activity in developing countries? Evidence from India. MPRA Paper No. 14495, http://www.mpra.ub.uni-muenchen.de/14995/

Athreye, S and S Kapur (2006). Industrial concentration in a liberalizing economy: a study of Indian manufacturing. Journal of Development Studies, 42(6), 981-999.

Balakrishnan, P, K Pushpangandan and MS Babu (2000). Trade liberalization and productivity growth in Indian manufacturing: evidence from firm level panel data. Economic and Political Weekly, 35, 3679-82.

Blomstrom, M and A Kokko (1998). Multinational Corporations and Spillovers. Journal of Economic Surveys, 12(3), 247-77.

Borensztein, E, J De Gregorio and J W Lee (1998). How does foreign direct investment affect economic growth? Journal of International Economics, 45, 115- 135.

Chen, T and A Kokko (2010). FDI and spillovers in China: non-linearity and absorptive capacity. CERC Working Paper 12, http://www.hhs.se/cerc.

Coe, D and E Helpman (1995). International R\&D spillovers. European Economic Review, 39 (5), 859-887.

Easterly, W (1993). How much do distortions affect growth? Journal of Monetary Economics, 32, $187-212$.

Findlay, R (1978). Relative Backwardness, direct foreign investment, and the transfer of technology: a simple dynamic model. Quarterly Journal of Economics, 92(1), 1-16.

Fosuri, A, M Motta and T Ronde (2001). Foreign direct investment and spillovers through workers’ mobility. Journal of International Economics, 53, 205-222.

Girma, S (2005). Absorptive capacity and Productivity Spillover from FDI: A threshold regression Analysis. Oxford Bulletin of Economics and Statistics, 67(3), 281-306.

Haddad, M and A Harrison (1993). Are there Positive Spillovers from Direct Foreign Investment? Evidence from Panel Data for Morocco. Journal of Development Economics, 42, 51-74. 
Hall, RE (1988). The relation between price and marginal cost in US industry. Journal of Political Economy, 96(5), 921-947.

Hamilton, JD and J Monteagudo (1998). The augmented Solow model and the productivity slowdown. Journal of Monetary Economics, 42(3), 495-509.

Helpman, E (1997). R\&D and productivity: the international connection. NBER Working Paper No. 6101, Cambridge, MA.

Jones, CI (1998). Introduction to Economic Growth. New York, Norton.

Kao, C and MH Chiang (1998). On the estimation and inference of a cointegrated regression in panel data. Working Paper, Center for Policy Research, Syracuse University.

Kohpaiboon, A (2006). Foreign Direct Investment and Technology Spillover: A Cross-Industry Analysis of Thai Manufacturing. World Development, 34, 541-556.

Kokko A (1992). Foreign Direct Investment, host country characteristics and spillovers. Ph.D. Thesis, Stockholm School of Economics.

Kokko, A (1994). Technology, market characteristics, and spillovers. Journal of Development Economics, 43, 279-293.

Kwark, NS and YS Shyn (2006). International R\&D spillovers revisited: human capital as an absorptive capacity for foreign technology. International Economic Journal, 20(2), 179-196.

Lichtenberg, F and B van Pottelsberghe de la Potterie (1998). International R\&D spillovers: A comment. European Economic Review, 42(8), 1483-1491.

Madsen, JB, S Saxena and JB Ang (2010). The Indian growth miracle and endogenous growth. Journal of Development Economics, 93(1), 37-48.

Mankiw, G, D Romer and DN Weil (1992). A contribution to the empirics of economic growth. Quarterly Journal of Economics, 107, 407-437.

Pedroni, P (1999). Critical values for cointegration tests in heterogeneous panel with multiple regressors. Oxford Bulletin of Economics and Statistics, 61, 653-670.

Pedroni, P (2000). Fully modified OLS for heterogeneous cointegrated panels. In: B.H. Baltagi (eds.), Nonstationary Panels, Panel Cointegration, and Dynamic Panels, Advances in Econometrics, 15(JAI), 93-130.

Pedroni, P (2001). Purchasing Power parity tests in cointegrated panel. The Review of Economics and Statistics, 83(4), 727-731.

Pedroni, P (2004). Panel cointegration: asymptotic and finite sample properties of pooled time series tests with an application to the PPP hypothesis. Econometric Theory, 20, 597-625. 
Rabbaie, A and L Hunt (2004). Panel unit roots and cointegration: evidence for OECD energy demand. IAEE European Conference, Zurich.

Ramirez, M (2007). Is foreign direct investment productive in the Latin America case? A panel unit root and panel cointegration analysis, 1980-2001. Yale University Working Papers on Economic Applications and Policy, No. 23.

Romer, PM (1990). Endogenous technological change. Journal of Political Economy, 98(5), S71 S102.

Sjoholm, F (1999). Technology gap, Competition and Spillovers from Direct Foreign Investment: Evidence from Establishment Data. The Journal of Development Studies, 36, 53-73.

Srivastava, V (1996). Liberalization, Productivity and Competition: A Panel Study of Indian Manufacturing. Oxford University Press, Delhi.

Srivastava, V (2000). The impact of India's economic reforms on industrial productivity, efficiency and competitiveness. Report of a project sponsored by the Industrial Development Bank of India, New Delhi, National Council of Applied Economic Research.

Stock JH and MW Watson (1993). A simple estimator of cointegrating vectors in higher order integrated systems. Econometrica, 61, 783-820.

Wang, JY and M Blomstrom (1992). Foreign Investment and Technology Transfer: A Simple Model. European Economic Review, 36, 137-155.

$\mathrm{Xu}, \mathrm{B}$ (2000). Multinational enterprises, technology diffusion and host country productivity growth. Journal of Development Economics, 62, 477-493. 
Table 1: A statistical summary of the key variables

\begin{tabular}{|l|l|l|l|l|}
\hline Variables & Mean & SD & Min & Max \\
\hline$L P d$ & 8.895 & 1.616 & 6.137 & 18.776 \\
\hline$L P d b s$ & 8.450 & 1.530 & 5.013 & 19.964 \\
\hline$L P d s z$ & 8.471 & 1.886 & 5.553 & 20.531 \\
\hline$k / l$ & 11.114 & 4.111 & 1.509 & 17.927 \\
\hline$k b s / l b s$ & 13.042 & 4.123 & 1.836 & 21.321 \\
\hline$k s z / l s z$ & 11.032 & 4.021 & 1.213 & 17.654 \\
\hline$k$ & 12.808 & 3.861 & 1.934 & 20.742 \\
\hline$k b s$ & 13.214 & 3.654 & 1.987 & 21.456 \\
\hline$k s z$ & 12.321 & 3.111 & 1.456 & 20.187 \\
\hline FORP & 0.173 & 0.160 & 0 & 0.732 \\
\hline$M C O N^{*} F O R P$ & 0.044 & 0.202 & 0 & 2.934 \\
\hline$T G A P$ & 0.669 & 0.429 & 0 & 1.926 \\
\hline$R D I D$ & 0.005 & 0.009 & 0 & 0.061 \\
\hline$R D I F$ & 0.005 & 0.005 & 0 & 0.069 \\
\hline$T M I D$ & 0.022 & 0.023 & 0 & 0.209 \\
\hline$T M I F$ & 0.030 & 0.049 & 0.0002 & 0.388 \\
\hline
\end{tabular}

Note: Mean = simple average; SD = standard deviation; Min = minimum; and Max = maximum.

Estimates of $L P d, L P d b s, L P d s z, k l, k b s / l b s, k s z / l s z, k, k b s$, and $k s z$ are logarithmic transformation of their value. The other variables are converted into logarithmic form as $\ln (1+x)$ where $x$ is the variable. No. of observations, $\mathrm{NT}=288$. 
Table 2: Panel Unit Root Tests

\begin{tabular}{|c|c|c|c|c|}
\hline Variables (levels) & LLC & Breitung & IPS & Hadri \\
\hline$L P d$ & -3.058 & -0.635 & -1.286 & $3.651 *$ \\
\hline$L P d b s$ & $-3.300 *$ & -1.123 & -3.427 & $5.830 *$ \\
\hline$L P d s z$ & -4.086 & -1.003 & -3.312 & $1.955^{*}$ \\
\hline$k / l$ & 0.168 & -0.512 & 1.860 & $8.513^{*}$ \\
\hline$k b s / l b s$ & 0.123 & -0.324 & 1.369 & 7.654* \\
\hline $\mathrm{ksz} / \mathrm{lsz}$ & 0.546 & -0.578 & 1.764 & $8.321 *$ \\
\hline$k$ & -3.904 & -7.510 & -4.365 & $4.298 *$ \\
\hline$k b s$ & -3.546 & -8.798 & -4.546 & $4.056 *$ \\
\hline$k s z$ & -3.897 & -8.474 & -4.564 & 4.879* \\
\hline TGAP & -3.853 & -4.651 & -4.281 & $0.608 *$ \\
\hline FORP & -4.384 & 0.965 & -4.039 & $2.119 *$ \\
\hline$M C O N * F O R P$ & -9.650 & 1.043 & -7.314 & $4.322 *$ \\
\hline$R D I D$ & 10.227 & -2.509 & -2.196 & $4.401 *$ \\
\hline$R D I F$ & -4.993 & -2.811 & $-4.128 *$ & $4.227^{*}$ \\
\hline TMID & -16.72 & -4.595 & -8.875 & $0.747 *$ \\
\hline TMIF & $-60.61^{*}$ & -2.466 & -21.33 & 4.841* \\
\hline
\end{tabular}

Note: 1 . Automatic selection of maximum lags. Automatic selection of maximum lags is based on SIC: 0 to 3 . 2. Newey-West bandwidth selection using Bartlett and Kernel.

3. A * indicates the rejection of null hypothesis of non-stationary (LLC, Breitung, IPS) or stationary (Hadri) at the $5 \%$ level of significance. 
Table 3: Panel Unit Root Tests

\begin{tabular}{|c|c|c|c|c|}
\hline $\begin{array}{l}\text { Variables (1 }{ }^{\text {st }} \\
\text { Differences) }\end{array}$ & LLC & Breitung & IPS & Hadri \\
\hline$L P d$ & $-13.321 *$ & $-3.551^{*}$ & $-13.105^{*}$ & -0.018 \\
\hline$L P d b s$ & $-15.276 *$ & $-5.418^{*}$ & $-12.281^{*}$ & 0.929 \\
\hline LPdsz & $-14.676^{*}$ & $-6.888^{*}$ & $-12.701^{*}$ & -0.026 \\
\hline$k / l$ & $-13.969 *$ & $-7.809 *$ & $-12.318^{*}$ & 3.262 \\
\hline$k b s / l b s$ & $-14.654^{*}$ & $-7.356^{*}$ & $-12.635 *$ & 3.546 \\
\hline $\mathrm{ksz} / \mathrm{lsz}$ & $-13.897^{*}$ & $-7.124 *$ & $-12.879 *$ & 3.124 \\
\hline$k$ & $-14.135^{*}$ & $-15.888 *$ & $-16.629 *$ & 8.933 \\
\hline$k b s$ & $-14.526^{*}$ & $-15.468 *$ & $-16.456 *$ & 8.956 \\
\hline$k s z$ & $-14.256^{*}$ & $-15.368 *$ & $-17.123^{*}$ & 8.631 \\
\hline TGAP & $-13.721 *$ & $-6.608 *$ & $-13.472 *$ & 7.957 \\
\hline FORP & $-18.048 *$ & $-4.659 *$ & $-14.383 *$ & 8.844 \\
\hline$M C O N * F O R P$ & $-15.844^{*}$ & $-5.270 *$ & $-13.913 *$ & 7.542 \\
\hline$R D I D$ & $-5.707^{*}$ & $-6.662^{*}$ & $-14.103^{*}$ & 4.361 \\
\hline$R D I F$ & $5.386 *$ & $-8.632^{*}$ & 17.067* & 5.971 \\
\hline TMID & $-9.695^{*}$ & $-9.216^{*}$ & $-12.956 *$ & 1.626 \\
\hline TMIF & $1.625^{*}$ & $-9.417^{*}$ & $-12.572 *$ & 4.046 \\
\hline
\end{tabular}

Note: 1. Automatic selection of maximum lags. Automatic selection of maximum lags is based on SIC: 0 to 3 2. Newey-West bandwidth selection using Bartlett and Kernel

3. A* indicates the rejection of null hypothesis of non-stationary (LLC, Breitung, IPS) or stationary (Hadri) at the $5 \%$ level of significance. 
Table 4: Panel Cointegration Test

\begin{tabular}{|c|c|c|c|}
\hline Model & \multicolumn{2}{|l|}{ Panel statistics } & Group panel statistics \\
\hline \multirow[t]{4}{*}{ Model (9) } & Panel V-Statistic & $\begin{array}{l}-3.139 \\
(0.156)\end{array}$ & \\
\hline & Panel Rho-Statistic & $\begin{array}{l}4.625 \\
(0.135)\end{array}$ & $\begin{array}{l}5.994 \\
(0.148)\end{array}$ \\
\hline & Panel PP-Statistic & $\begin{array}{l}-5.922 \\
(0.013) \\
\end{array}$ & $\begin{array}{l}-5.121 \\
(0.095) \\
\end{array}$ \\
\hline & Panel ADF-Statistic & $\begin{array}{l}-7.566 \\
(0.003)\end{array}$ & $\begin{array}{l}-4.503 \\
(0.102)\end{array}$ \\
\hline \multirow[t]{4}{*}{ Model (10) } & Panel V-Statistic & $\begin{array}{l}-2.547 \\
(0.325) \\
\end{array}$ & \\
\hline & Panel Rho-Statistic & $\begin{array}{l}-7.087 \\
(0.045)\end{array}$ & $\begin{array}{l}-6.695 \\
(0.082) \\
\end{array}$ \\
\hline & Panel PP-Statistic & $\begin{array}{l}-6.245 \\
(0.036)\end{array}$ & $\begin{array}{l}-5.212 \\
(0.095)\end{array}$ \\
\hline & Panel ADF-Statistic & $\begin{array}{l}-6.505 \\
(0.083)\end{array}$ & $\begin{array}{l}-7.765 \\
(0.038)\end{array}$ \\
\hline \multirow[t]{4}{*}{ Model (11) } & Panel V-Statistic & $\begin{array}{l}-2.674 \\
(0.123)\end{array}$ & \\
\hline & Panel Rho-Statistic & $\begin{array}{l}4.422 \\
(0.156)\end{array}$ & $\begin{array}{l}5.585 \\
(0.782)\end{array}$ \\
\hline & Panel PP-Statistic & $\begin{array}{l}-6.114 \\
(0.053)\end{array}$ & $\begin{array}{l}-7.613 \\
(0.012)\end{array}$ \\
\hline & Panel ADF-Statistic & $\begin{array}{l}-8.115 \\
(0.060)\end{array}$ & $\begin{array}{l}-5.427 \\
(0.050) \\
\end{array}$ \\
\hline
\end{tabular}

Note: 1. An intercept but no trend was included in estimation. Numbers in round parenthesis are p-values. Figures in square brackets are t-statistics. * indicates $1 \%$ level significance.

2. Row 2 represents panel cointegration of endogenous variable $L P d$ with respect to the regressors in empirical Model (9).

3. Row 3 represents panel cointegration of endogenous variable $L P d b s$ with respect to the regressors in empirical Model (10).

4. Row 4 represents panel cointegration of endogenous variable $L P d s z$ with respect to the regressors in empirical Model (11). 
Table 5: Panel GFMOLS and DOLS Results, Explaining Labor Productivity

\begin{tabular}{|l|l|l|l|l|l|l|}
\hline \multicolumn{2}{|l|}{$\begin{array}{l}\text { Dependent variable } \\
\text { LPd }\end{array}$} & \multicolumn{2}{l|}{$\begin{array}{l}\text { Dependent variable } \\
\text { LPdbs }\end{array}$} & \multicolumn{2}{l|}{$\begin{array}{l}\text { Dependent variable } \\
\text { LPdsz }\end{array}$} \\
\hline$(1)$ & $\begin{array}{l}(2) \\
\text { GFMOLS }\end{array}$ & $\begin{array}{l}(3) \\
\text { DOLS }\end{array}$ & $\begin{array}{l}(4) \\
\text { GFMOLS }\end{array}$ & $\begin{array}{l}(5) \\
\text { DOLS }\end{array}$ & $\begin{array}{l}(6) \\
\text { GFMOLS }\end{array}$ & $\begin{array}{l}(7) \\
\text { DOLS }\end{array}$ \\
\hline$k / l$ & $1.15^{*}$ & 0.24 & $1.55^{*}$ & 0.130 & -0.12 & 0.16 \\
& $(4.44)$ & $(0.12)$ & $(6.21)$ & $(0.06)$ & $(-0.40)$ & $(0.23)$ \\
\hline$k$ & $2.74^{*}$ & 0.009 & $1.42^{*}$ & 0.014 & $4.69^{*}$ & 0.07 \\
& $(6.41)$ & $(0.13)$ & $(5.01)$ & $(0.07)$ & $(2.80)$ & $(0.26)$ \\
\hline FORP & $6.23^{*}$ & $1.25^{*}$ & 3.49 & $1.45^{* *}$ & $3.28^{*}$ & $3.47^{*}$ \\
& $(1.75)$ & $(2.87)$ & $(0.96)$ & $(1.59)$ & $(2.66)$ & $(5.37)$ \\
\hline MCON* & -3.30 & $0.959^{*}$ & $1.77^{*}$ & $1.90^{*}$ & -6.17 & $1.83^{* *}$ \\
FORP & $(-0.52)$ & $(6.19)$ & $(3.54)$ & $(3.45)$ & $(-0.93)$ & $(1.59)$ \\
\hline TGAP & $-1.31^{* *}$ & -1.08 & $-0.13^{*}$ & 0.049 & $-1.03^{*}$ & $-1.64^{* *}$ \\
& $(-1.65)$ & $(0.76)$ & $(-2.12)$ & $(0.42)$ & $(-5.94)$ & $(-1.43)$ \\
\hline RDID & $5.27^{*}$ & $2.42^{*}$ & $2.64^{*}$ & $3.99^{*}$ & -1.50 & $2.56^{*}$ \\
& $(1.85)$ & $(6.22)$ & $(5.83)$ & $(2.47)$ & $(0.78)$ & $(2.64)$ \\
\hline RDIF & 7.74 & $1.75^{*}$ & $1.60^{*}$ & $2.45^{*}$ & $6.42^{*}$ & -0.44 \\
& $(-0.12)$ & $(2.43)$ & $(1.72)$ & $(3.21)$ & $(5.23)$ & $(0.09)$ \\
\hline TMID & $3.54^{*}$ & $3.52^{*}$ & 0.32 & $2.58^{*}$ & $6.18^{*}$ & $-3.71^{*}$ \\
& $(2.36)$ & $(2.83)$ & $(0.23)$ & $(2.72)$ & $(3.71)$ & $(-2.73)$ \\
\hline TMIF & 3.14 & $2.05^{*}$ & $1.34^{*}$ & 0.84 & $1.49^{*}$ & $3.40^{*}$ \\
& $(0.49)$ & $(2.17)$ & $(3.62)$ & $(1.20)$ & $(3.50)$ & $(4.06)$ \\
\hline
\end{tabular}

Note: 1. The DOLS regressions include one lead and one lag for the differenced regressors. AR Lags in Computing is $S(0) 1$.

2. The columns (2) and (3) stand for the long-run estimates of $L P d$ with respect to the regressors in empirical Model (9).

3. The Columns (4) and (5) stand for the long-run estimates of $L P d b s$ with respect to the regressors in empirical Model (10). In case of Model (10), we are taking $k b s / l b s$ and $k b s$ in place of $k / l$ and $k$.

4. The columns (6) and (7) stand for the long-run estimates of $L P d s z$ with respect to the regressors in empirical Model (11). In case of Model (11), we are taking $k s z / l s z$ and $k s z$ in place of $k / l$ and $k$.

5. A* denotes statistical significance at least at the $5 \%$ level, while ** represents at the $10 \%$ level.

6. Absolute t-statistics are in the parenthesis. NT=288. 
Table 6: FMOLS Regressions over the Period 1990-2007 in Sixteen Industries of Indian Manufacturing (Individual FMOLS Results)

Dependent variable $L P d$

\begin{tabular}{|c|c|c|c|c|c|c|c|c|c|}
\hline $\begin{array}{l}\text { Variables } \\
\text { Industries }\end{array}$ & $k / l$ & $k$ & FORP & $\begin{array}{l}\text { MCON* } \\
\text { FORP }\end{array}$ & TGAP & $R D I D$ & $R D I F$ & TMID & TMIF \\
\hline Food Products & $\begin{array}{l}-0.93 \\
(-0.56)\end{array}$ & $\begin{array}{l}3.75^{*} \\
(3.67)\end{array}$ & $\begin{array}{l}2.78^{*} \\
(2.40)\end{array}$ & $\begin{array}{l}-3.85 \\
(-1.02)\end{array}$ & $\begin{array}{l}-0.02 \\
(-0.23)\end{array}$ & $\begin{array}{l}-0.62 \\
(-0.52)\end{array}$ & $\begin{array}{l}1.25^{*} \\
(2.58)\end{array}$ & $\begin{array}{l}3.95^{*} \\
(2.15)\end{array}$ & $\begin{array}{l}-2.82 \\
(-0.51)\end{array}$ \\
\hline $\begin{array}{l}\text { Beverages } \\
\text { and Tobacco }\end{array}$ & $\begin{array}{l}7.23^{*} \\
(5.76)\end{array}$ & $\begin{array}{l}6.28^{*} \\
(4.63)\end{array}$ & $\begin{array}{l}0.52^{*} \\
(2.42)\end{array}$ & $\begin{array}{l}-0.33 \\
(-0.32)\end{array}$ & $\begin{array}{l}-0.04^{*} \\
(-4.97)\end{array}$ & $\begin{array}{l}2.42^{*} \\
(2.76)\end{array}$ & $\begin{array}{l}-0.34 \\
(-0.32)\end{array}$ & $\begin{array}{l}0.60^{*} \\
(1.74)\end{array}$ & $\begin{array}{l}-1.51 \\
(0.60)\end{array}$ \\
\hline Cotton Textiles & $\begin{array}{l}0.24 \\
(-1.17)\end{array}$ & $\begin{array}{l}4.17^{*} \\
(2.80)\end{array}$ & $\begin{array}{l}0.43^{* *} \\
(1.32)\end{array}$ & $\begin{array}{l}-3.47 \\
(-0.72)\end{array}$ & $\begin{array}{l}0.01 \\
(0.01)\end{array}$ & $\begin{array}{l}-6.13 \\
(-1.00)\end{array}$ & $\begin{array}{l}-3.14^{*} \\
(-1.68)\end{array}$ & $\begin{array}{l}3.28 \\
(1.24)\end{array}$ & $\begin{array}{l}-0.57 * * \\
(-1.62)\end{array}$ \\
\hline Textiles & $\begin{array}{l}0.38^{*} \\
(2.59)\end{array}$ & $\begin{array}{l}1.96^{*} \\
(2.76)\end{array}$ & $\begin{array}{l}6.03^{* *} \\
(1.53)\end{array}$ & $\begin{array}{l}4.50 \\
(0.16)\end{array}$ & $\begin{array}{l}-0.22 * \\
(-2.03)\end{array}$ & $\begin{array}{l}-1.14 \\
(-0.30)\end{array}$ & $\begin{array}{l}-0.81 \\
(-1.23)\end{array}$ & $\begin{array}{l}-1.27 \\
(-0.83) \\
\end{array}$ & $\begin{array}{l}0.66 \\
(0.64)\end{array}$ \\
\hline Woods Products & $\begin{array}{l}-0.83 \\
(-0.74)\end{array}$ & $\begin{array}{l}2.43^{* *} \\
(1.34)\end{array}$ & $\begin{array}{l}0.14^{*} \\
(3.69)\end{array}$ & $\begin{array}{l}5.55 \\
(0.85)\end{array}$ & $\begin{array}{l}0.09 \\
(0.49)\end{array}$ & $\begin{array}{l}5.28 * \\
(2.65)\end{array}$ & $\begin{array}{l}-0.96^{*} \\
(-2.09)\end{array}$ & $\begin{array}{l}2.82^{*} \\
(2.40)\end{array}$ & $\begin{array}{l}-1.25 \\
(-0.96)\end{array}$ \\
\hline $\begin{array}{l}\text { Paper and } \\
\text { Paper Products }\end{array}$ & $\begin{array}{l}0.64 * * \\
(1.63)\end{array}$ & $\begin{array}{l}2.65^{*} \\
(4.92)\end{array}$ & $\begin{array}{l}0.22 \\
(0.55)\end{array}$ & $\begin{array}{l}1.88^{*} \\
(2.78)\end{array}$ & $\begin{array}{l}-0.96^{*} \\
(-3.48)\end{array}$ & $\begin{array}{l}2.92^{*} \\
(2.02)\end{array}$ & $\begin{array}{l}1.08 \\
(0.06)\end{array}$ & $\begin{array}{l}2.20^{*} \\
3.01)\end{array}$ & $\begin{array}{l}2.12^{*} \\
(4.40)\end{array}$ \\
\hline Leather Products & $\begin{array}{l}0.32 * * \\
(1.44)\end{array}$ & $\begin{array}{l}-0.35 \\
(-1.05)\end{array}$ & $\begin{array}{l}0.10 \\
(0.31)\end{array}$ & $\begin{array}{l}0.93^{*} \\
(3.95)\end{array}$ & $\begin{array}{l}-2.40 * \\
(-3.98)\end{array}$ & $\begin{array}{l}3.31^{*} \\
(1.96)\end{array}$ & $\begin{array}{l}3.88^{*} \\
(2.84)\end{array}$ & $\begin{array}{l}1.68^{*} \\
(3.02)\end{array}$ & $\begin{array}{l}-1.58 \\
(-1.02)\end{array}$ \\
\hline Chemicals & $\begin{array}{l}-1.44^{* *} \\
(-1.53)\end{array}$ & $\begin{array}{l}-2.26 \\
(-1.06)\end{array}$ & $\begin{array}{l}2.41^{*} \\
(1.81)\end{array}$ & $\begin{array}{l}3.72^{*} \\
(1.82)\end{array}$ & $\begin{array}{l}-2.16^{*} \\
(-3.40)\end{array}$ & $\begin{array}{l}1.69 \\
(0.93)\end{array}$ & $\begin{array}{l}3.17 \\
(0.87)\end{array}$ & $\begin{array}{l}2.16 \\
(0.70)\end{array}$ & $\begin{array}{l}1.48^{*} \\
(1.94)\end{array}$ \\
\hline $\begin{array}{l}\text { Drugs } \\
\text { and Pharmaceuticals }\end{array}$ & $\begin{array}{l}0.90^{*} \\
(6.05)\end{array}$ & $\begin{array}{l}3.66^{*} \\
(5.82)\end{array}$ & $\begin{array}{l}3.69 * \\
(4.48)\end{array}$ & $\begin{array}{l}2.28 \\
(0.94)\end{array}$ & $\begin{array}{l}-1.96^{*} \\
2.67) \\
\end{array}$ & $\begin{array}{l}1.01^{*} \\
(2.95)\end{array}$ & $\begin{array}{l}2.70^{*} \\
(4.28)\end{array}$ & $\begin{array}{l}-0.62 \\
(-1.04)\end{array}$ & $\begin{array}{l}3.18^{*} \\
(7.28)\end{array}$ \\
\hline $\begin{array}{l}\text { Rubber and } \\
\text { Rubber Products }\end{array}$ & $\begin{array}{l}-0.25 \\
(-0.31)\end{array}$ & $\begin{array}{l}-5.79 \\
(-0.09)\end{array}$ & $\begin{array}{l}0.17^{*} \\
(3.27)\end{array}$ & $\begin{array}{l}2.29 * \\
(1.78)\end{array}$ & $\begin{array}{l}-0.37 \\
(-1.25)\end{array}$ & $\begin{array}{l}-8.08 \\
(-0.59)\end{array}$ & $\begin{array}{l}2.85^{*} \\
(1.80)\end{array}$ & $\begin{array}{l}-2.32 \\
(-0.78)\end{array}$ & $\begin{array}{l}0.04 \\
(0.42)\end{array}$ \\
\hline $\begin{array}{l}\text { Non-metallic } \\
\text { Mineral Products }\end{array}$ & $\begin{array}{l}0.68^{*} \\
(2.47)\end{array}$ & $\begin{array}{l}6.43^{* *} \\
(1.28)\end{array}$ & $\begin{array}{l}6.16^{*} \\
(1.35)\end{array}$ & $\begin{array}{l}-2.04^{*} \\
(-2.58)\end{array}$ & $\begin{array}{l}-4.18 * \\
(-5 . .90)\end{array}$ & $\begin{array}{l}2.79 * \\
(5.96)\end{array}$ & $\begin{array}{l}-2.96 \\
(-1.26)\end{array}$ & $\begin{array}{l}-0.32 \\
(-0.06)\end{array}$ & $\begin{array}{l}4.03^{*} \\
(6.69)\end{array}$ \\
\hline Metal Products & $\begin{array}{l}2.81^{*} \\
(5.06)\end{array}$ & $\begin{array}{l}2.80 * \\
(6.03)\end{array}$ & $\begin{array}{l}2.07 \\
(3.45)\end{array}$ & $\begin{array}{l}4.91^{*} \\
(4.37)\end{array}$ & $\begin{array}{l}0.10 \\
(0.71)\end{array}$ & $\begin{array}{l}2.58^{* *} \\
(1.35)\end{array}$ & $\begin{array}{l}-2.16 \\
(-1.06)\end{array}$ & $\begin{array}{l}1.92 \\
(0.82)\end{array}$ & $\begin{array}{l}3.92^{*} \\
(2.11)\end{array}$ \\
\hline $\begin{array}{l}\text { Non-Electrical } \\
\text { Machinery }\end{array}$ & $\begin{array}{l}1.17^{*} \\
(2.82)\end{array}$ & $\begin{array}{l}1.60^{*} \\
(2.14)\end{array}$ & $\begin{array}{l}-0.64 \\
(-0.16)\end{array}$ & $\begin{array}{l}5.41 \\
(0.79)\end{array}$ & $\begin{array}{l}-1.74^{*} \\
(-7.36)\end{array}$ & $\begin{array}{l}0.11 \\
(0.00)\end{array}$ & $\begin{array}{l}-0.36^{*} \\
(-2.38)\end{array}$ & $\begin{array}{l}3.24^{* *} \\
(1.54)\end{array}$ & $\begin{array}{l}-1.45 \\
(-0.69)\end{array}$ \\
\hline $\begin{array}{l}\text { Electrical } \\
\text { Machinery }\end{array}$ & $\begin{array}{l}1.31 * \\
(3.57)\end{array}$ & $\begin{array}{l}6.73 \\
(0.91)\end{array}$ & $\begin{array}{l}0.24 \\
(0.18)\end{array}$ & $\begin{array}{l}5.73^{* *} \\
(1.43)\end{array}$ & $\begin{array}{l}-0.91 * \\
(-2.40)\end{array}$ & $\begin{array}{l}-3.25 \\
(-0.15)\end{array}$ & $\begin{array}{l}3.01^{*} \\
(3.96)\end{array}$ & $\begin{array}{l}0.61^{*} \\
(2.44)\end{array}$ & $\begin{array}{l}2.2 *^{*} \\
(3.17)\end{array}$ \\
\hline $\begin{array}{l}\text { Consumer } \\
\text { Electronics }\end{array}$ & $\begin{array}{l}-0.79^{* *} \\
(-1.40)\end{array}$ & $\begin{array}{l}5.41^{*} \\
(1.94)\end{array}$ & $\begin{array}{l}1.62 \\
(0.97)\end{array}$ & $\begin{array}{l}1.98^{*} \\
(3.34)\end{array}$ & $\begin{array}{l}-0.40^{*} \\
(-5.53)\end{array}$ & $\begin{array}{l}6.64 \\
(1.00)\end{array}$ & $\begin{array}{l}6.03^{*} \\
(3.26)\end{array}$ & $\begin{array}{l}5.58 \\
(1.17)\end{array}$ & $\begin{array}{l}2.50^{*} \\
(2.25)\end{array}$ \\
\hline Automobiles & $\begin{array}{l}0.82 * \\
(6.58)\end{array}$ & $\begin{array}{l}0.62^{*} \\
(3.39)\end{array}$ & $\begin{array}{l}0.47^{*} \\
(3.77)\end{array}$ & $\begin{array}{l}8.21^{*} \\
(4.07)\end{array}$ & $\begin{array}{l}0.22^{* *} \\
(1.42)\end{array}$ & $\begin{array}{l}-2.97 \\
(-0.86)\end{array}$ & $\begin{array}{l}3.39 * * \\
(1.44)\end{array}$ & $\begin{array}{l}6.74^{*} \\
(2.11)\end{array}$ & $\begin{array}{l}7.41^{*} \\
(3.96)\end{array}$ \\
\hline
\end{tabular}

Note: 1. Coefficients are long run estimates of $L P d$ with respect to the regressors in empirical Model (9).

2. An * denotes statistical significance at least at the $5 \%$ level, while an ** represents at the $10 \%$ level.

3. Absolute t-statistics are in the parenthesis. NT=288. 